\title{
CAPTIVE INSURANCE COMPANIES: DO THEY PROVIDE "INSURANCE"?
}

Stewart McCulloch

This article explores captive insurance companies and focuses on whether a true "insurance" relationship exists between captive insurer and its insured. After providing a general background to captives the article briefly visits the legal definition of "insurance" and then considers the captive insurer/insured relationship to determine whether an "insurance" relationship exists. Finally, the article considers situations where the existence or absence of a true "insurance" relationship may be of significance.

\section{WHAT IS A CAPTIVE INSURANCE COMPANY?}

The Winebox papers ${ }^{1}$ (which contain material referring to captive insurance companies) and the Securities Commission enquiry into certain arrangements undertaken by the Bank of New Zealand ${ }^{2}$ which were described as being based on captive insurance principles ${ }^{3}$ ) have highlighted the use of captive insurance companies. The propriety of the use of such entities has also been called into question with the Securities Commission commenting "... it is also apparent from the domicile of most of the captives that many are formed to provide tax advantages for their owners, with or without genuine insurance cover".

A "captive insurance company" is nothing more than an insurance company which is owned by its insureds. Such companies derive the name since they have a "captive" market. Under this definition, a mutual insurance company ${ }^{5}$ would be a captive insurance company.

- Barrister and Solicitor of the High Court of New Zealand. This article is based a research paper submitted partial fulfilment of the LLM degree at Victoria University of Wellington.

1 Papers presented, by leave, to the House of Representatives by the member for Tauranga, the Hon Winston Peters MP, on 16 March 1994, 1-10.

2 Securities Commission Report of an Enquiry into Certain Arrangements Entered into by the Bank of New Zealand in March 1988 (Wellington, 1993).

3 Above n 2, 74.

4 Above n 2, 72.

5 For example, AMP or National Mutual prior to its demutualisation. 
Normally, however, the phrase is used to describe more closely held insurance companies. A "pure" captive is a company which has only one owner and which insures only its owner (and its owner's affiliates). This article is concerned with "pure" captives and considers the extent to which such companies have a true "insurance" relationship with their insureds.

\section{A Background to Captive Insurance Companies}

The captive (ie a wholly owned subsidiary of a non-insurance related group of companies) has become an established feature of insurance over the past 40 years, particularly overseas. Estimates put the number of captives at over 3,000 controlling NZ $\$ 20$ billion per annum of premiums worldwide. ${ }^{6}$

In its most basic form, a captive operates like any other insurance company. It receives premiums from an insured and will settle claims in accordance with policy terms and conditions. The fundamental difference is that a captive is wholly owned by its insured. In order to limit its own exposure, especially to catastrophes, the captive will usually obtain reinsurance. It is this access to reinsurance markets which is often cited as the principal benefit of captives.

New Zealand's involvement with captives is small. There are at least nine New Zealand owned captives, four of which are domestic. ${ }^{8}$ The others are located in Vanuatu, Guernsey, Hawaii and the Cook Islands. A review of the Annual Reports of some New Zealand companies reveal the following captives:

\begin{tabular}{|c|c|c|}
\hline Parent Company & Captive & Location \\
\hline $\begin{array}{l}\text { Coal Corporation of New Zealand } \\
\text { Limited }\end{array}$ & CoalCorp Insurance Services Limited & New Zealand \\
\hline $\begin{array}{l}\text { Electricity Corporation of New } \\
\text { Zealand Limited }\end{array}$ & $\begin{array}{l}\text { Electricity Corporation of New } \\
\text { Zealand Insurance Limited }\end{array}$ & New Zealand \\
\hline Fletcher Challenge Limited & Terraces Insurances Limited & Guernsey \\
\hline $\begin{array}{l}\text { Telecom Corporation of New } \\
\text { Zealand Limited }\end{array}$ & Teleco Insurance Inc & USA \\
\hline
\end{tabular}

$6 \quad$ Above n 2, 73.

7 CF Teniswood “Risk Retention and Captive Insurance in a Corporate Risk Management Programme" in 1994 InterData Risk Handbook, 66.

8 Jeff Wilson Evaluating the Taxation Advantages of Setting Up a Captive to Manage Uninsurable and Insurable Risk (Institute of International Research Conference on Managing Uninsurable Risk, Wellington, 1994) 5. 


\section{Underlying Rationale}

Commercially, insurance has traditionally been sought to maintain financial stability following the occurrence of adverse events. Without such protection the ability of a business to continue trading could be severely undermined. However, the use of insurance to maintain financial stability may not be cost effective in the long term since:

- Where insurance covers regularly recurring incidents causing losses of fairly predictable magnitude (eg motor vehicle claims) premiums paid are usually "experience rated". Accordingly, the annual cost of losses is calculated and the insurer will add a margin to cover overhead expenses and profit. As a result, insurance of these types of claims merely increases the cost of such losses."

- In other circumstances, the premiums may well be "class rated" based on the view that the insurer takes of risks within the insured's industry category. Since the rate of premium will be industry based, there is insufficient flexibility to recognise differing levels of risk within an industry. As a result, companies with a good record of risk management will end up paying (through higher premiums) for the losses of other companies. $^{10}$

- The percentage margin on insurance premiums varies depending upon market conditions and the type of risk. However, typically, an insurer will aim to apportion $60 \%$ to $70 \%$ of premiums to the cost of claims with the balance covering the insurer's own expenses, profit and brokerage.

- In calculating the premium, generally no account will be taken of interest carried on premiums held by the insurer. Certain "long tail" risks, (such as public liability, and professional liability claims) often take a long time to settle. As a result, insurers can have substantial funds earning interest.

Accordingly, in the long term, the cost of premiums to an insured will exceed the cost of claims by the insurance company's overheads and profit. In some circumstances therefore, it may be more cost effective for an organisation to finance losses arising from adverse events directly from earnings. This would eliminate the additional cost of an insurer's overhead and profit and also enable the organisation to retain the investment income otherwise earned by an insurer. This "self-insurance" strategy would also enable the organisation to pay for its own losses rather than subsidising the losses of other organisations.

9 International Risk Management (Australia) Pty Ltd “Captive Insurance” in 1994 InterData Risk Handbook, 59.

10 Above $\mathbf{n} 9$.

11 PA Bawcutt Captive Insurance Companies: Establishment, Operation and Management (3ed, Woodhead-Faulkener, London, 1991) 13. 
While large organisations have the propensity to self-insure minor regularly occurring risks, there will still be a need for insurance protection against a catastrophic loss. The optimal cost-effective approach to risk management is therefore a combination of selfinsurance and conventional insurance. Insurance protection against a catastrophic loss is often most economically obtained by accessing the "wholesale" or reinsurance market, where insurance companies themselves buy protection against adverse underwriting results.

Generally it is not possible for a commercial organisation seeking insurance to access the reinsurance market directly. This is because reinsurers will usually be restricted from offering insurance to the public by the legislation of the jurisdiction in which they are based. Accordingly, only insurance companies will generally have access to reinsurance markets. Therefore in order for a non-insurance company to access the reinsurance market it is necessary for the company to contract with reinsurers through a captive.

In by-passing the "retail" insurance market and accessing the "wholesale" reinsurance market the captive is able to reduce the cost of premiums by controlling and/or eliminating commissions paid to intermediaries. Such commissions can be an important cost element in the make up of an insurance premium and substantial savings are possible. ${ }^{12}$ In addition to the elimination of commissions paid to intermediaries, access to reinsurance markets by captives can provide the following benefits:

- Premiums can be based on the ultimate insured's expected claim experience rather than an industry as a whole

- $\quad$ Captives can enjoy cashflow advantages. Unlike direct insurance where premiums are paid in advance, payments made by a captive insurer to a reinsurer are generally made at the close of a pre-determined period. ${ }^{13}$

- Insurance can be provided for certain risks which the normal insurance market will not accept, or to obtain broader types of insurance which the commercial insurance companies do not have the flexibility to provide. ${ }^{14}$

- The level of risk retained by the captive can vary from time to time depending upon the state of the reinsurance market. For example, in a market where cost effective insurance is difficult to obtain the captive may increase its level of risk retention. When the market softens and insurance becomes available, the captive can negotiate favourable contracts.

12 Above $n$ 11, 26.

13 B Spitz Tax Havens Encyclopaedia (Butterworths, London, 1994) 3.

14 Above n 11, 27. 


\section{Tax Drive A Myth?}

Captives are often thought to be tax driven. According to the Securities Commission "it is also apparent from the domicile of most of the captives that many are formed to provide tax advantages for their owners, with or without genuine insurance cover". ${ }^{15}$ Historically this may have been true. The tax drive being that premiums paid by the insured to its captive would be tax deductible in the insured's home country as a business expense. However, the premium derived by the captive would not be subject to income tax since the captive would be located in a tax haven. Certainly, prior to the 1980s this tax drive existed. However, many jurisdictions in the world (including New Zealand) have introduced tax rules which eradicate the ability of shareholders to defer income derived by offshore companies. ${ }^{16}$ In New Zealand these rules, known as "Controlled Foreign Company" ("CFC") rules, were enacted in 1988 . $^{17}$

The exact nature of the CFC rules differ from jurisdiction to jurisdiction. In general terms however, where a shareholder of a particular country owns more than, say, $10 \%$ of a foreign company which is controlled by residents of that country, the shareholder is required to "attribute" or treat as his or her own income, his or her share of the foreign company's income. In relation to captives, this means that the owner would be taxable on any income derived by the captive, even though the captive might be resident in a foreign jurisdiction. As a result, it is now a misconception that captives are tax driven. Most captives are established for insurance reasons and tax is not a primary consideration. ${ }^{18}$

Contrary to the view of the Securities Commission expressed above, the underlying reasons for the formation of a captive in a foreign jurisdiction are usually of an insurance and business nature quite apart from any fiscal benefits which may accrue. ${ }^{19}$ The reason that many captives are located in tax haven jurisdictions is not for tax purposes but to take advantage of more flexible rules relating to insurance companies in the tax haven jurisdiction and avoid controls located in the country of the parent company. ${ }^{20}$ For example, tax haven jurisdictions generally allow insurance companies to invest surplus

Above n 2,73.

Above n 11, 199.

The CFC rules are contained in Part CG, Income Tax Act 1994.

Above n 9, 59.

Above n 5, 3.

Above n 11, 34. 
accommodations relatively freely, including investing for the direct or indirect benefit of the parent or other affiliated companies.

\section{DO CAPTIVES PROVIDE "INSURANCE"?}

In New Zealand there is a dearth of legislative or judicial pronouncements on captives. Given the very small number of captives operating in New Zealand this is not surprising. There are no court cases on record dealing with captives. While New Zealand legislation contains references ${ }^{22}$ to captives, these references do little more than acknowledge their existence. This article next explores the captive insurer/insured relationship to determine whether a true "insurance" relationship exists. As a starting point the common law definition of insurance is briefly visited followed by a consideration of cases from the United States, Canada and Australia. The possible approach by New Zealand courts is then explored.

\section{A The Common Law Position}

It is generally agreed among the text writers that there is no all embracing definition of a "contract of insurance" nor even the term "insurance" itself. ${ }^{23}$ According to the texts, the traditional starting point for a definition of insurance emanates from the judgment of Channel $\mathrm{J}$ in Prudential Insurance Co $v$ Inland Revenue Commissioners. ${ }^{24}$ In that case, Channel $\mathrm{J}$ doubted that an adequate definition of insurance could ever be given. ${ }^{25}$ However, he went on to set out the following three essential features of a contract of insurance. ${ }^{26}$

- The contract must be one whereby for some consideration (usually but not necessarily periodical payments called premiums) the insured secures to himself or herself some benefit (usually but not necessarily the payment of a sum of money) upon the happening of some event.

- The event should involve some element of uncertainty either as to whether it will ever happen, or if the event is inevitable, as to when it will happen.

21 AM Tamosius "The Enigma of Offshore Captives" in M Grundy (ed) The Report of Offshore Financial Services 1996/97 (Campden Publishing Ltd, Hong Kong, 1996) 65.

22 See s 415(3), Companies Act 1955 (since repealed) and also s 4(1)(b), Insurance Companies (Ratings and Inspections) Act 1994 which removes the need for a captive to have a current claims paying rating.

23 Kelly and Ball Principles of Insurance Law in Australia and New Zealand (Butterworths, Sydney, 1991) para 1.10; Tarr and Kennedy Insurance Law in New Zealand (2ed, The Law Book Company, Sydney, 1992) para 1.2.

$24[1904] 2$ KB 658.

25 Above $n$ 24, 662 .

26 Above n 24, 662-663. 
- The insured must have an interest in the subject matter of the insurance.

These requirements have been discussed and explored in subsequent cases and have become established as the essential defining characteristics of an insurance contract. ${ }^{27}$ Based solely on the above requirements, a contract between captive insurer and insured could be drafted so as to satisfy the elements of an insurance contract. There, are however, a number of additional factors which may be relevant in determining whether or not a contract between captive insurer and insured may truly be described as "insurance". These factors include:

1 The extent to which a court would be likely to lift the "corporate veil" and treat the captive and its owner as one economic entity.

2 The possible classification of the purported contract as a"sham".

3 The concept of "risk transference".

The following briefly outlines the above factors before considering the approach of overseas jurisdictions.

\section{Lifting the corporate veil}

The fundamental attribute of a company, that it is a legal entity distinct from its members, was enunciated in the case of Salomon $v$ Salomon $\& \mathrm{Co}^{28}$ The principle laid down in Salomon remains largely intact although over the years a number of statutory provisions and cases have sometimes penetrated the corporate veil. According to Gower, ${ }^{29}$ these instances reveal no constant principle beyond a refusal by the legislature and the judiciary to apply the logic of the principle laid down in Salomon were it is too flagrantly opposed to justice, convenience or the interests of the Revenue. After reviewing the decisions which have lifted or have refused to lift the corporate veil, Gower ${ }^{30}$ laments the unpredictability and inconsistency of the courts. He notes that much will depend on who will benefit or be damnified if the veil is lifted and also upon the nature of the legal issue. He suggests that if it concerns the construction of a commercial contract and a rigid application of the corporate entity principle would defeat the probable intention of the parties, the courts will tend to put a construction upon it which involves disregarding that principle.

27 See for example, RL Carter Reinsurance (Kluwer Publishing Ltd, London, 1979) 3; and Hardy Ivamy General Principles of Insurance Law (5ed, Butterworths, London, 1986) 3-4.

28 [1897] AC 22.

29 LCB Gower Gower's Principles of Modern Company Law (4ed, Stevens \& Son, London, 1979) 112. 
Farrar and Russell also canvass the cases concerned with corporate veil. They conclude $^{31}$ that it is difficult to sum up these exceptions except to say that the departures from the Salomon principle seem to be based on policy decisions. The general rule appears to be that the Salomon principle will be applied unless there is some reason to the contrary. Certainly this is the approach of the Court of Appeal in New Zealand. In Re Securitibank Ltd (No 2), ${ }^{32}$ a case concerning the discounting of bills of exchange between members of the same group of companies, the Court stressed that the starting point should be the application of the Salomon principle and any departure from it must be looked at very carefully.

With regard to captives, the application of the Salomon principle has not been tested in New Zealand. However, it is suggested that a New Zealand court would probably respect the separate legal identity of captive insurer and insured. As noted by the commentators above, the application of the Salomon principle is not easy to predict. It may be that a court faced with a deserving set of circumstances may pierce the corporate veil and refuse to recognise the separate entities by possibly treating the captive insurer as agent for the insured.

\section{Sham transactions}

Another principle which may affect a New Zealand court's interpretation of the captive insurer/insured relationship is whether or not the insurance contract reflects the true agreement between the parties. Where the insurance contract does not reflect the parties' true intention, the contract could be set aside as a sham. ${ }^{33}$ The application of the "sham" principle to captives has not been tested in New Zealand. However, it is submitted that, provided a purported insurance contract between captive insurer and insured accurately reflected the common intentions of the contracting parties, a New Zealand court would be required to respect it. The approach of other jurisdictions to the application of the "sham" principle is considered later in the article.

\section{The concept of "risk transference"}

Interestingly, absent from the common law definitions quoted above is the explicit recognition of the transfer of risk from the insured to the insurer. Kelly and Ball ${ }^{34}$ acknowledge "risk transference" as central to the concept of insurance. They argue that in

31 Farrar and Russell Company Law and Securities Regulations in New Zealand (Butterworths, Wellington, 1985).

33 For an explanation of the concept of sham, see Snook $v$ London West Riding Investment Ltd [1967] 1 All ER 518, 528-529. In the New Zealand context, see Mills $v$ Dowdall [1983] NZLR 154, 159; Marac Life Assurance Ltd $v$ Commissioner of Inland Revenue (1986) 8 NZTC 5086, 5087; and NZI Bank Ltd $v$ Euro National Corp Ltd [1992] 3 NZLR 528, 539.

34 Above n 23, paras $1.11-1.13$. 
distinguishing between insurance contracts and other contracts a better approach is to concentrate on the purpose of an insurance contract. This purpose, they say, is to transfer the risk of loss that arises from the insured's interest in the subject matter of the insurance to the insurer. It is this transfer of risk from the insured (who has information about the risk) to the insurer (who has no information) which Kelly and Ball argue justifies treating insurance contracts differently from other contracts. In particular, the imposition of the duty of utmost good faith and is ensuing disclosure obligations can be linked to the concept of risk transference. Kelly and Ball also suggest that although the duty of good faith may originally have been regarded as arising because a contract was one of insurance, it has now become one of the main criteria for deciding whether a contract is one of insurance.

Although not stated by Kelly and Ball, the "risk transference" principle has been subject to a substantial amount of case law in the United States, particularly in relation to captives. It is therefore convenient to now consider the approach taken in the United States in more detail.

\section{B The United States Approach}

Unlike the position in Common Law countries, the United States has a wealth of case law concerning captives. These cases are almost exclusively concerned with determining whether the premium paid by the insured is deductible for income tax purposes. Primarily due to the United States courts' application of the concept of "risk transference" the majority of captive cases have concluded that no insurance relationship exists between a captive insurer and its insured. This "risk transference" concept was first espoused by the Supreme Court in Helvering $v$ Le Gierse ${ }^{35}$ and has been extremely influential in subsequent cases. This part of the article briefly discusses the decision in Helvering $v$ Le Gierse and subsequent cases which involved captives.

\section{Helvering $v$ Le Gierse}

Less than a month before her death in 1936, the decedent, then aged 80, executed two contracts with a life insurance company. The first contract was a "single premium life-time annuity". A premium of $\$ 4,179$ entitled the decedent to annual payments of $\$ 589.80$ as long as she lived. The second contract was called a "single premium life policy" and provided for a payment of $\$ 25,000$ to the decedent's daughter (Le Gierse) on the death of the decedent in return for an upfront premium of $\$ 22,946$.

The "insurance" policy would not have been issued without the annuity contract, but in all other respects the insurance company treated the two contracts as distinct transactions. Neither contract referred to the other. Independent applications were filed for each. 
Neither premium was calculated with reference to the other. Premium payments were reported separately and entered in different accounts in the company's books. Separate reserves were maintained for insurance and annuities. Less than one month after the contracts were signed, the elderly woman died and the face value of the "insurance" contract become payable to Le Gierse. Under the provisions of the estate duty legislation applying at the time ${ }^{36}$ amounts "receivable as insurance" were excluded from a deceased's estate. The executors filed a federal estate tax return excluding the $\$ 25,000$ received by Le Gierse. The Commissioner of Inland Revenue (Helvering) disagreed and assessed the estate including the $\$ 25,000$ on the basis that the amount was not "receivable ... as insurance".

After analysing the language and apparent purpose of the statute, the Court concluded that the term "insurance" as used in the legislation did not have a specialised meaning but was to be interpreted in the ordinary way:

Historically and commonly insurance involves risk-shifting and risk distributing. That life insurance is desirable from an economic and social standpoint as a device to shift and distribute risk of loss from premature death is unquestionable. That these elements of riskshifting and risk-distributing are essential to a life insurance contract is agreed by courts and commentators .. Accordingly, it is logical to assume that when Congress used the words "receivable as insurance" in [the estate duty legislation] it contemplated amounts received pursuant to transactions possessing these features.

In holding that the $\$ 25,000$ receivable by Le Gierse was not "receivable as insurance", the ourt found that the annuity and "insurance" policy could not be treated as separate transactions. To do so would ignore actuality since all parties conceded that the "insurance" policy would not have been issued without the annuity contract. In the court's view, considered together, the contracts wholly failed to spell out any element of insurance risk. The annuity and the "insurance" policy were opposites which, when combined, neutralised the risk inherent in the other. In other words, the total $\$ 27,125$ received up front by the insurer was sufficient to fund the annual $\$ 589.80$ payment required under the annuity, the eventual $\$ 25,000$ payment required on death and also provide an income return to the insurer. Accordingly, the court found that the $\$ 25,000$ was not "receivable ... as insurance" and was not excluded from the decedent's gross estate.

Though Le Gierse dealt with life insurance in the domestic context, subsequent US case law has established that the principles from the case apply to intercorporate insurance and in particular that an arrangement may not be characterised as "insurance" if it lacks one of the essential ingredients of insurance, that is, "risk shifting" or "risk distributing". 


\section{Commissioner of Internal Revenue $v$ Treganowan ${ }^{38}$}

In Le Gierse the Supreme Court did not define what it meant by the terms "risk shifting" and "risk distribution". In Treganowan the Second Circuit was required to apply the principles enunciated in Le Gierse to payments received from the New York Stock Exchange Gratuity Fund. Since 1873 the Exchange Gratuity Fund provided the means of payment of $\$ 20,000$ by the surviving members to the families of deceased members. The constitution of the Exchange required each member to make a $\$ 15$ donation to the Gratuity Fund upon joining the Exchange. In addition, each member was required to make a $\$ 15 \mathrm{gift}$ on the death of each fellow member. As a result, when a member died, sufficient funds would be available for the member's family to receive $\$ 20,000$. The Fund always contained sums substantially in excess of that required for current payments. By 1941 the Fund contained almost $\$ 2,000,000$ and a constitutional amendment was adopted permitting the income from the Fund to be credited against amounts otherwise payable by surviving members so long as the value of the Fund remained in excess of $\$ 500,000$. Accordingly, members of the Exchange were no longer required to make actual contributions to the Fund.

The issue for the Court was similar to that in Le Gierse as to whether the $\$ 20,000$ sum received by the widow of a Stock Exchange member was "life insurance" and therefore was required to be included in the deceased's estate for estate tax purposes. The lower court had decided that the above arrangement was not "insurance" and was therefore not subject to estate duty. In doing so it stressed such matters as the lack of adjustment of premiums to health or age or living habits of the member, or of any requirement as to the passing of a physical examination, of any fixing of the amount of the "gift" with reference to his life expectancy as determined by mortality tables.

The decision was appealed to the Second Circuit which considered the decision in Le Gierse and also referred to a Yale Law Journal article which criticised the decision in the lower court. ${ }^{39}$ The Court in Treganowan quoted the following passage from that article:

Risk shifting emphasises the individual aspect of insurance: the effecting of a contract between the insurer and insured each of whom gamble on the time the latter will die. Risk distribution, on the other hand, emphasises the broader social aspect of insurance as a method of dispelling the danger of a potential loss by spreading its cost throughout a group. By diffusing the risks through a mass of separate risk shifting contracts, the insurer casts his lot with the law of averages. The process of risk distribution, therefore, is the very essence of insurance.

38183 F2d 288 (1950).

39 "The New York Stock Exchange Gratuity Fund: Insurance That Isn't Insurance" (1950) 59 Yale Law Journal 780.

40 Above $n$ 38, 291. The quote is from above $n 39,783$. 
It is interesting to note that the article itself described the basis of the decision in Le Gierse as "cryptic" and lamented that "despite twenty years of stormy litigation in the estate tax field, the statutory term "insurance" has otherwise gone undefined". ${ }^{41}$ Despite this criticism of the Le Gierse decision, the court in Treganowan applied the "risk shifting" and "risk distribution" concepts and found that the amount received by the widow was "life insurance" and was required to be included in the deceased's gross estate for estate tax purposes.

As an aside, it is interesting to note that in both the United States and in Common Law the leading cases ${ }^{42}$ which have defined insurance in both jurisdictions have involved two common elements. Firstly, the cases dealt with life insurance as opposed to general insurance. Secondly, the cases have involved the Revenue as a party to the litigation. Nothing appears to rest on these factors and, in both jurisdictions, the principles founded in these cases have subsequently been applied in all areas of insurance.

\section{Internal Revenue Service approach}

The Internal Revenue Service ("IRS") has played a significant and active role in the development of case law concerning captives. For US Federal Income Tax purposes, the principal difference between insurance company and general corporate taxation is the insurer's ability to report premium on an earned basis and to recognise losses on an incurred bases. The net result is a deferral of the recognition of income by the captive insurer. In order to eliminate this perceived advantage, in 1977 the IRS issued Revenue Ruling 77-316 dealing with the issue of tax deductibility for premiums paid to a whollyowned insurance subsidiary. In that Ruling the IRS denied the existence of an insurance relationship between captive insurer and the insured on the basis that there is no risk shifting or risk distribution outside the corporate group or "the economic family". In other words, within each "economic family", the persons bearing the ultimate economic burden of loss were the same as those who suffer the loss. Under this reasoning, "premiums" payable by an insured to a captive were not for "insurance". As a result, the amounts paid were not deductible as an ordinary and necessary business expense. Instead such premiums were deemed to be contributions of capital and not taxable to the captive.

The approach of the IRS in restricting tax deductibility of premiums was seen as "very hard line", 43 and has produced a series of cases concerning the deductibility of premiums paid to captive insurers. Smith notes that the IRS has been influential in developing the case

41 Above n 38, 782.

42 Above nn 24, 35.

43 BD Smith "Analysing the Tax Deductibility of Premiums Paid to Captive Insurers" (1986) 53 Journal of Risk and Insurance 85. 
law and "has systematically settled cases out of court which it felt might set an unfavourable precedent in the legal system, and it has gone to trial only in those circumstances where its case is strong".

\section{Carnation $v$ Commissioner of Internal Revenue}

The first in a line of captive cases was Carnation Co $v$ Commissioner of Internal Revenue. ${ }^{45}$ In that case, Carnation, a US resident company, entered into insurance contracts with an unrelated insurer. That insurer reinsured 90 percent of its risk with Three Flowers, a wholly owned subsidiary of Carnation located in Bermuda. Because the insurer was not fully satisfied that Three Flowers would be able to meet its financial obligations, it required Carnation, as a condition for writing its insurance policies, to agree to provide an additional $\$ 2,880,000$ of capital to Three Flowers if required by that company. The position of the parties is presented diagrammatically as follows:

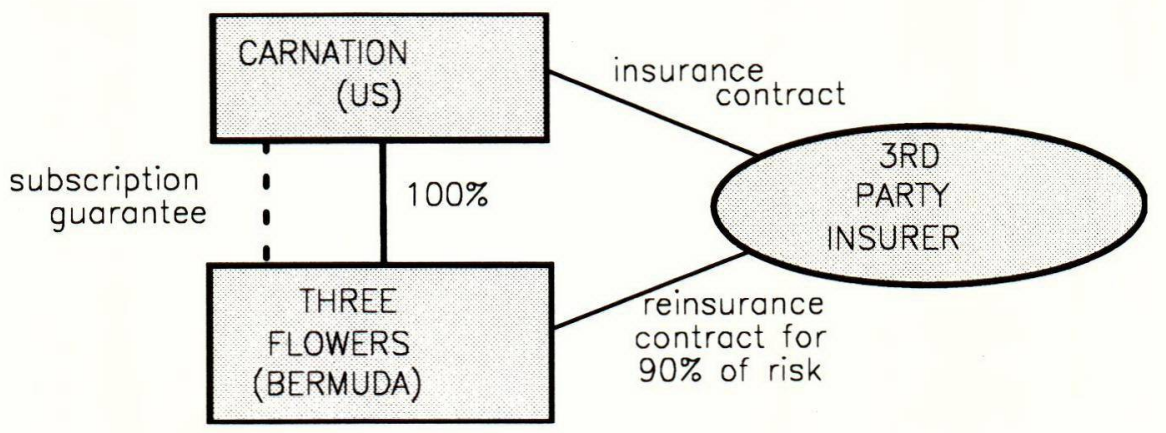

According to the court, the two interdependent agreements, the insurance contract between the insurer and Carnation and the indemnity agreement between Carnation and Three Flowers, negated the existence of insurance. Carnation's risks, initially borne by the outside insurer, were 90 per cent reinsured with Three Flowers. Three Flowers subsequently was being guaranteed by the original insured, Carnation. The court ruled that no risk had passed from Carnation due to the existence of these interdependent transactions. Accordingly, the amounts paid by Carnation were not for "insurance" and were therefore not deductible for income tax purposes.

A number of similar cases have followed Carnation. ${ }^{46}$ With few exceptions, the cases found that the purported arrangement between captive and insured was found not to be one

44 Above n 43, 89.

4571 TC 400 (1978), aff d, 81-1 UST C 9263, 640 F 2d 1010 (1981).

46 For example, Stearns-Roger Corp v United States 774 F2d 414 (1985); Beech-Aircraft Corp v United States 84-2 USTC 9803 (D Kan); Clougherty Packaging Co v Commissioner 84 TC 948 (1985); Mobil Oil Corp v United 
of insurance due to lack of risk-shifting and risk distribution. Accordingly, a deduction for the "insurance" premium paid was denied. According to Knight and Knight, a number of conclusions regarding the deductibility of payments to a captive can be drawn from the Carnation line of cases:

First, the two elements of risk-shifting and risk-distributing determine whether a purported insurance contract is, in fact, insurance. Second, interdependent agreements - e.g. insurance between A and B and reinsurance of B's risk with $C$ - are considered together in determining whether risk-shifting and risk distributing have occurred. Third, whether or not the entity seeking the deduction indemnifies the losses of the captive is not determinative if the assets of the entity decline as claims are paid. Fourth, payments by a parent to a wholly owned captive subsidiary that fails to provide "significant" insurance to unrelated parties generally will not be deductible because of a lack of risk-shifting and risk-distributing. Fifth, the Tax Court has extended its finding of no risk shifting in parent-subsidiary relationships to brothersister arrangements. Finally, the Tax Court has stated that it is reluctant to base its decision on the economic family concept of Rev Rul 77-316. Critics charge that this reluctance stems from a fear that the concept violates the separate entity doctrine of Moline_Properties.

The "separate entity" doctrine referred to in the above paragraph is the American equivalent of the common law principle emanating from Salomon discussed above. Some of the judgments in the American cases quite clearly override the separate entity status of the captive and analyse the relationship between captive and insured from the perspective of the overall corporate group. Other judgments however, state that the separate entity status of the captive should be respected but still conclude that the captive insurer/insured relationship is not one of insurance.

States 769 F2d 196; Humana Inc and Subsidiaries v Commissioner 88 TC 188 (1987); Gulf Oil v Commissioner 89 TC No 70 (1987); Crawford Fitting Co v US 606 F Supp 136 (1985)

47 LG Knight and RA Knight "Securing a Deduction for Payments to Captive Insurance Companies : Crawford Shows the Way" (1988) 66 Taxes 374, 382. 


\section{The Canadian Approach}

The Canadian jurisdiction provides one case concerning the captive insurer/insured relationship, Consolidated-Bathurst $v$ The Queen. ${ }^{49}$ Again the issue arose in the context of a tax dispute. The relationship between the parties is set out diagrammatically below:

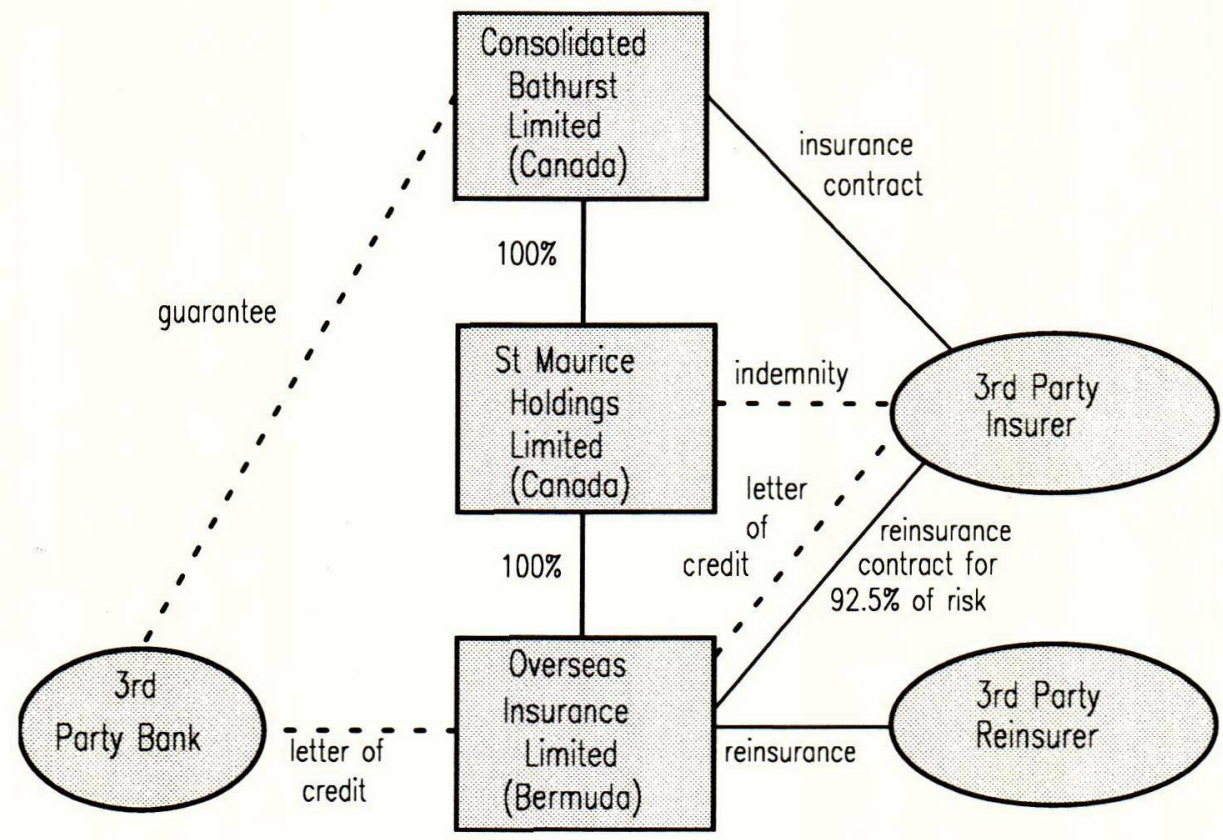

In Consolidated-Bathurst $v$ The Queen the insured (Consolidated-Bathurst) incorporated a wholly-owned sub subsidiary (Overseas Insurance Limited) to act as a captive insurer. The reasons given for its creation included:

- The difficulty and expense of obtaining direct insurance.

- Avoiding Canadian insurance industry regulation.

- $\quad$ Avoiding Canadian income tax.

- $\quad$ Satisfying trust deed conditions for securing corporate indebtedness.

The captive was incorporated in Bermuda and managed by a Bermudan corporation. It had no employees of its own. During the 1971 to 1975 years Consolidated-Bathurst took out certain insurance policies with Canadian insurance companies. These insurers in turn reinsured over 90 per cent of the risks with the captive. Some of the captives risks were 
further reinsured with third party reinsurers. During the 1971 to 1974 years, the third party insurer received an indemnity from St Maurice, and Consolidated-Bathurst provided a guarantee for the captive's letter of credit. During the 1975 year no indemnity nor guarantee was given.

In its income tax returns for the 1971 to 1975 income years, Consolidated-Bathurst claimed a tax deduction for the insurance premiums paid to the third party insurer. The Canadian tax authority disallowed the premiums to the extent of the amounts retained by the captive and not expended on reinsurance premiums. In the Federal Court Trial Division, ${ }^{50}$ the court denied the deduction for the premium paid by Consolidated-Bathurst. In doing so, the court considered two sections of the Canadian Income Tax Act 1952.

18(1) In computing the income of a taxpayer from a business or property no deduction shall be made in respect of .....

(e) an amount transferred or credited to a reserve, contingent account or sinking fund except as expressly permitted by this Part.

245(1) In computing income for the purposes of this Act, no deduction may be made in respect of a disbursement or expense made or incurred in respect of a transaction or operation that, if allowed, would unduly or artificially reduce the income.

The court accepted that the captive was created to serve several purposes including bone fide business purposes and did not constitute a sham. However, after considering the principles of risk-shifting and risk-distribution enunciated in Helvering $v$ Le Gierse the court concluded that the risk which Consolidated-Bathhurst had sought to insure had not been shifted. This was because the captive did not have sufficient assets to cover the potential losses and therefore Consolidated-Bathurst would have effectively borne these losses. Accordingly the net result was similar to the establishment of a reserve fund and were not deductible by virtue of $s$ 18(1)(e) of the Income Tax Act. In addition, the Federal Court Trial Division considered that the disbursements artificially reduced the income of Consolidated-Bathurst and were not deductible under s 245(1) of the Income Tax Act. The court also considered that the "economic family" concept should apply since the risk was retained within the same group of companies and accordingly did not involve a true shifting of risk.

The case was appealed to the Canadian Federal Court of Appeal. In that court, the deductions were denied in the 1971 to 1974 years but were allowed in the 1975 year. In relation to the 1971 to 1974 years the Court of Appeal considered that, due to the indemnity 
arrangements, Consolidated-Bathurst could have been required to absorb a portion of the loss it had purported to insure. In the court's view: ${ }^{51}$

A contract of insurance is a contract to indemnify an insured for losses incurred to the full extent provided in the contract according to its terms and conditions. In my view, an arrangement or condition whereby an insured may be required to absorb any portion of the loss for which indemnity is so provided does not result in bone fide insurance protection.

Accordingly the premiums had artificially reduced the company's income and were not deductible under s 245(1) of the Income Tax Act. With regard to the 1975 income year however, the court considered that in the absence of any guarantee arrangement there was a genuine transfer of risk and distribution thereof among the insurers and reinsurers. Accordingly the insurance premiums paid in the 1975 income year did not result in an artificial reduction of the company's income and were therefore deductible. In coming to the conclusion, the Court of Appeal emphatically rejected the "economic family" concept. In the court's view the "adoption of that concept would amount to a wholesale disregard of separate corporate existence regardless of the circumstances in a particular case. I find that to be unacceptable."

\section{The Australian Approach}

The recent Australian decision in WD \& HO Willis (Australia) Pty Ltd $v$ FC of $T^{52}$ also dealt with the deductibility for income tax purposes of insurance premiums paid to a captive. Interestingly, the Federal Commissioner of Taxation did not raise as an issue whether the relationship between the captive and its insured was bone fide insurance. Instead the Commissioner relied on the Australian Tax Act's anti-avoidance provisions ${ }^{53}$ and argued that the captive was created for the dominant purpose of enabling a tax benefit to be obtained.

Although not necessary for the court to decide the point, Sackville J noted that in his view there was no doubt that the contract between the captive and insured was properly classified as a contract of insurance. ${ }^{54}$ With regard to the tax avoidance arguments the court found that the captive had been created for bone fide commercial purposes and that any taxation advantage was incidental to the principle objectives. Accordingly, the premium was deductible to the insured for tax purposes.

51 Above n 49, 62.

52 Fed Ct - Sackville J; 1 March 1996, Ref Nos: NG 262-5 of 1994.

53 Part IVA, Income Tax Assessment Act 1936.

54 Above $n 52,64$. 
The decision in Wills and, in particular, the apparent acceptance by the Federal Commissioner of Taxation of a bone fide insurance relationship is interesting. On 11 August 1994 the Australian Tax Office ("ATO") issued a draft ruling concerning the deductibility of premiums paid to captive insurance companies. ${ }^{55}$ That ruling (expressed as being the "preliminary, though considered" views of the $\mathrm{ATO}^{56}$ ) discusses what the ATO considers will constitute an "acceptable insurance arrangement". The draft ruling commences with a discussion of the common law definition of insurance emanating from Prudential $^{57}$ and provides a text book definition. The draft ruling then proceeds to consider a number of United States cases including Helvering $v$ Le Gierse ${ }^{58}$ and discusses in some detail the concepts of risk shifting and risk-distributing. The draft ruling appears to accept the applicability of these concepts to Australian law without question. The draft ruling concludes that in the absence of sufficient risk shifting and risk distributing captive insurance arrangements would not be considered by the ATO as constituting "insurance" for tax purposes.

\section{E The Approach of the New Zealand Courts}

Having briefly considered the approach of other jurisdictions, this part of the article considers the approach New Zealand courts would take when considering whether the captive insurer/insured relationship was truly on of "insurance".

\section{The concept of "risk transference"}

The starting point of any enquiry by a New Zealand court will inevitably be the common law definition of insurance as enunciated by Channel $\mathrm{J}$ in Prudential ${ }^{59}$ and developed over the years in a number of subsequent cases. As noted, absent from the common law definitions is the explicit recognition of the transfer of risk from the insured to the insurer. The extent to which a New Zealand court would take notice of the American concepts of risk shifting and risk distribution emanating from Helvering $v$ Le Gierse is difficult to predict. Certainly, the application of the principle has not been ruled out. In Marac Life Assurance Ltd $v$ Commissioner of Inland Revenue 60 the court was asked to determine whether certain short term bonds issued by Marac were policies of life insurance.

55 Income Tax: Captive Insurance Companies Deductibility of Premiums and the Appropriate Basis of Assessment (Draft Ruling TR 94/D36, 11 August 1994) Australian Tax Office.

56 Above $\mathrm{n} 55,1$.

57 Above $\mathbf{n} 24$.

58 Above $n 35$.

59 Above $\mathrm{n} 24$.

60 [1986] 1 NZLR 694; (1986) 8 NZTC 5086. 
Having determined that the bonds were endowment insurance and therefore policies of life insurance it was not necessary for the court to consider the concept of "risk transference". This was acknowledged by Richardson J who stated "Nor is it necessary to review the emphasis placed in some of the American authorities on risk taking by the insurer as interest in the concept of life insurance". 61

Based on the above, while the concept of "risk transference" has been acknowledged by the New Zealand courts, it has neither been adopted nor rejected. Accordingly, the question is still open as to whether such a concept should or should not apply in New Zealand. However, it is doubted whether the American case law would be so readily adopted by the New Zealand courts as it was in Canada in Consolidated-Bathurst or in Australia by the Australian Tax Office.

\section{Sham transactions}

A New Zealand court would, it is suggested, consider the concept of "sham" to determine whether the purported insurance contract accurately reflected the parties' intention. This analysis was undertaken by the court in the Canadian case of Consolidated-Bathurst. In that case, the court accepted that the captive was created to serve several purposes including bone fide business purposes and did not constitute a sham. Based on the approach of the New Zealand Court of Appeal to "shams" it is submitted that, provided a purported insurance contract between captive insurer and insured accurately reflected the common intentions of the contracting parties, a New Zealand court would be reluctant to characterise the contract as a sham. According to Richardson J in NZI Bank ${ }^{62}$ "at common law there is no halfway house between sham and characterisation of the transaction according to the true nature of the legal arrangements entered into and carried out."

61 Above n 60, 705 and 5096. The American cases cited to the court in Marac included Helvering $v$ Le Gierse. See above n 2, 52.

62 Above n 33, 539. 


\section{Ownership structure}

The ownership structure of the captive will also be an important consideration. Consider the following two possibilities:
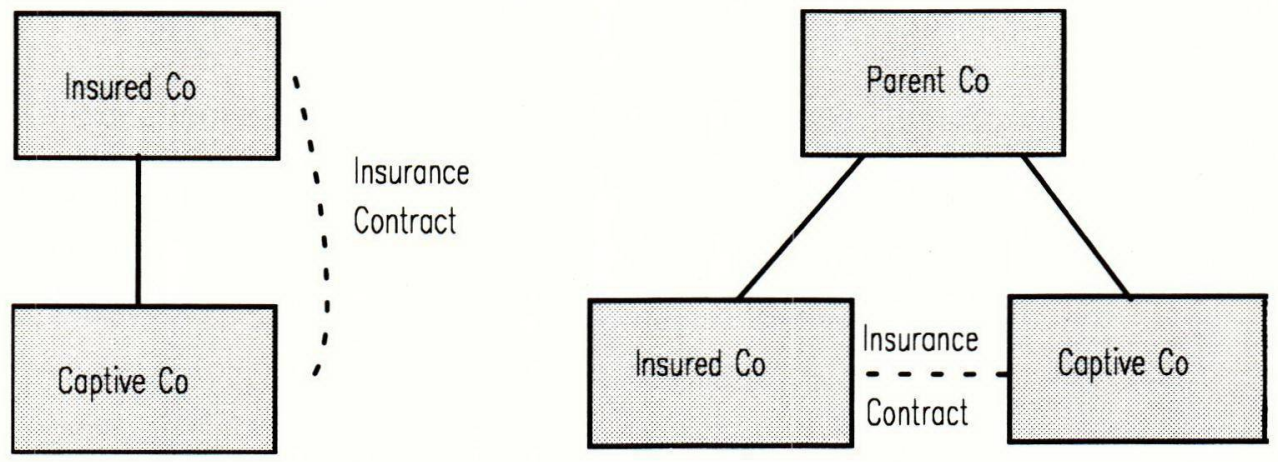

It is submitted that it would clearly be easier for a court to find an insurance relationship between sister subsidiaries. In that case, looked at from the perspective of Insured $\mathrm{Co}$, the risk of loss has clearly been transferred. If a loss arises, the financial position of Insured Co would be protected regardless of the consequences to Parent Co and Captive Co.

This distinction has even been recognised by the American courts in Humana Inc $v$ The Commissioner of Internal Revenue 63 in which it was held that premiums paid by a "brother" company to its "sister" insurance affiliate were made in respect of a true insurance relationship. The "brother" company had shifted its risk of loss to the captive because the assets of the insured company did not bear the economic impact of a loss paid by its sister captive company.

In other American cases such as Carnation discussed above, the courts have refused to recognise a true insurance relationship between a Parent Company and its wholly owned captive insurance company. According to the courts, in the wholly owned context, there is no risk-shifting because a loss sustained by the insurance subsidiary would cover the value of its stock, which would the be reflected on the balance sheet of the parent/insured. As a result, the parent bears the economic impact of a loss paid by the insurance subsidiary and cannot be said to have shifted its risk of loss.

This does not mean however, that a parent/captive relationship cannot give rise to a true insurance relationship. In the Canadian case of Consolidated-Bathurst a bona fide contract of insurance was established between parent and subsidiary. It is submitted that, 
in New Zealand, the ownership structure of the captive, while relevant, would not be determinative as to whether a true insurance relationship existed.

\section{Lifting the corporate veil}

With regard to lifting the corporate veil it is suggested that a New Zealand court would be more reluctant to pierce or lift the corporate veil than its American counterpart. However, as noted earlier, ${ }^{64}$ it is always possible that in the appropriate circumstance the separate entity status of a corporate group might be disregarded. This would be consistent with the approach of Stone J in Consolidated-Bathurst who, while emphatically rejecting the "economic family" concept, left open the possibility of lifting the corporate veil in the circumstances of a particular case. ${ }^{65}$

\section{Legislation}

Another factor impacting on a New Zealand court's approach to the issue might be legislation. For example, in Consolidated-Bathurst the Canadian Federal Court of Appeal was required to focus on the issue in the context of tax legislation which concentrated on the "artificiality" of the arrangement. Interestingly, in that case, the court noted the absence of such legislation in the United States and considered the extent to which the absence of legislation influenced the courts in the United States. ${ }^{66}$ In New Zealand, this particular aspect could be significant. For example, where the issue arises in a taxation context the anti-avoidance provisions of the Income Tax Act 1994 will need to be considered. ${ }^{67}$ Those sections provide that where an arrangement has as one of its purposes the purpose of avoiding tax, the arrangement can be treated as void as against the Commissioner. Accordingly, it could be possible for a captive insurance arrangement - even if valid for insurance law purposes - to be characterised by a court as tax avoidance and therefore set aside. As a result, it may not be necessary for a court to determine whether or not the arrangement gives rise to a true insurance relationship.

\section{Ancillary arrangements}

The existence of ancillary arrangements outside of the formal written insurance contract may also be relevant for the court to consider. Certainly, this factor influenced the American cases. In Le Gierse the court found that when the two contracts were considered together, they cancelled each other out. Similarly, in Carnation the existence of a guarantee by the owner/insured was influential. According to the court in that case, the two

64 Above Part II B.

65 Above n 49, 63.

66 Above n 49, 63.

67 Section BB9. 
interdependent agreements (the insurance contract between the captive and the insured and the indemnity agreement between the insured and the captive) negated the existence of insurance. In Consolidated-Bathurst the court found that in those years in which a parental guarantee was present no insurance relationship existed. However, in the absence of a parental guarantee the court was prepared to accept that a true insurance relationship existed.

\section{Summary}

A New Zealand court, when faced with the issue of determining whether a true insurance relationship exists between captive insurer and insured, would not be restricted to merely considering the formal written contract between the parties. The court would look at a wide range of difference issues and factors including those outlined in this paper. Given the variety of factual circumstances in which the issue may arise, it is difficult to predict the outcome of a New Zealand court's consideration of this issue. It is suggested however that a New Zealand court would not adopt the American "economic family" approach. Instead a New Zealand court would analyse the insurance relationship taking a more traditional common law approach. The outcome of any particular case may be influenced by the mischief giving rise to the enquiry. Accordingly, the next part of the article considers the circumstances in which a dispute could arise which may require the New Zealand courts to consider this issue.

\section{WHAT DOES IT MATTER?}

Since captives are, by definition, owned by their insurers, it is unlikely that any contractual dispute will arise between the parties. It is even more unlikely that any dispute arising would be required to be settled by way of litigation in the courts. Since the companies involved will have the same ultimate owners it would be in the best interests (ie less costly) for those owners to have any disagreement settled by agreement rather than adjudication. This is so even where the dispute is between sister companies since, under the Companies Act 1993, directors of a subsidiary are permitted to act in the best interests of their parent company. ${ }^{68}$ However, there may be circumstances where it is necessary to determine whether an insurance relationship truly exists between the captive insurer and the insured. This part of the article considers the position of parties other than the captive insurer and insured to determine in what circumstances a dispute may arise which may require resort to the New Zealand courts. 


\section{A Tax Authorities}

Based on overseas experience, the primary focus of the issues which have been litigated relate to tax. A detailed analysis of the New Zealand income tax implications of captives is beyond the scope of this article. However, apart from possible minor issues relating to the timing of recognition of income and expenditure, there appears to be little reason for the New Zealand Inland Revenue Department to dispute whether or not the relationship between captive insurer and insured is not one of true "insurance". 69

\section{B Change of Ownership}

One possible circumstances in which captive insurer/insured relationship may be litigated in New Zealand is where a change in ownership occurs in the insured. For example, a corporate group may have a number of subsidiaries who each place insurance through the group's captive. If one of the subsidiaries is sold outside the group the new owners, of the company will be different from the owners of the captive. Accordingly, should a dispute arise in relation to the insurance contract between the company and the captive, amicable settlement of the dispute to the mutual benefit of each party may not be possible. Resort to litigation may be necessary.

\section{Accounting}

With the introduction of the Financial Reporting Act 1993 and its elevation of the status of accounting standards, the accounting treatment of insurance in general, and captive insurance in particular will demand more attention. As evidenced by the Securities Commission's enquiry into the "insurance" arrangements entered to by the Bank of New Zealand, the accounting treatment of insurance arrangements and, in particular those based on captive insurance principles is far from clear. With accounting's focus on substance over legal form, it is more likely for the American principles of "risk shifting" and "risk distribution" to dominate over the legal nature of the transaction. In addition, the separate corporate entity status of a captive insurance company within a group will be more difficult to sustain. Certainly auditors who will be required to sign off on the financial statements will be reluctant to stray from a conservative approach.

\section{Insurance Legislators}

As noted earlier New Zealand has an absence of legislation specifically targeted at captives. Like most insurance companies, captives are required to comply with the Insurance Companies Deposits Act 1953 and deposit $\$ 500,000$ with the Public Trustee upon

69 See SJ McCulloch “Captive Insurance Companies: Do They Provide Insurance?" LLM Research Paper, VUW, 1995. 
commencing business. ${ }^{70}$ However, captive insurance companies are excluded from the operation of Part I of the Insurance Companies (Ratings and Inspections Act) $1994^{71}$ thereby eliminating the need to obtain a credit rating.

\section{E Bankers and Other Providers of Finance}

In Consolidated-Bathurst $v$ The Queen ${ }^{72}$ one of the reasons given for the formation of the captive was that "insurance coverage was essential in order that the appellant could satisfy conditions of trust deeds securing corporate indebtedness". A requirement to obtain adequate insurance of a company's assets is a common requirement in most financing transactions. Failure to maintain such insurance could give rise to the right of the lender to demand repayment. It is possible that a dispute may arise between the provider of finance and an insured as to whether a captive insurer has provided adequate "insurance", and accordingly whether the right of the lender to demand repayment has arisen.

\section{F Reinsurers}

The issue as to whether the captive insurer/insured relationship is one of insurance may be crucial where the captive has reinsured all or part of its risk to a reinsurer. For example, the regulatory regime applying in the jurisdiction in which the reinsurer is based may prohibit the reinsurer from transacting with the public and limit the reinsurer to contracting with insurance companies only. Should the captive not be providing true "insurance", the reinsurer may be in breach of its jurisdiction's regulatory regime. Perhaps of more significance may be the possibility of a reinsurer disputing the payment of a claim on the grounds that the captive is not providing bona fide insurance.

\section{CONCLUDING COMMENTS}

Based on the above analysis it can be concluded that the issue as to whether, in legal terms, there is a true "insurance" relationship between captive insurer and insured is unresolved, for New Zealand purposes at least. The area most likely for the issue to be raised in New Zealand, as it has been overseas, is that of taxation. To date there have been no public announcements from the New Zealand Inland Revenue Department regarding captives. This is not surprising given New Zealand's small number of large companies and limited number of captives established to date. However, there are a number of factors emerging in New Zealand which may be conducive to the increasing use of captives. These factors include:

70 Section 4, Insurance Companies Deposits Act 1953.

71 Section 4(1)(b).

72 Above n 49. 
- The enactment of the Resource Management Act 1993 which imposes a number of responsibilities and liabilities concerning the environment.

- The recent reform of company law and financial reporting which imposes greater obligations on directors and officers of companies.

- The shift to "user pays" in the health sector and the increased reliance on medical insurance.

- Contracting out of the Accident Compensation and Rehabilitation Insurance Act 1992 by accredited employers.

- Phasing out of the role of the Earthquake Commission in the insurance of property.

The above factors will increase the focus of companies, particularly larger companies on risk management and ensuring an effective and efficient insurance programme. It is possible that companies with established captives will increase their role to cover some or all of the above areas. In addition other companies may be encouraged to investigate the feasibility of creating a captive to assist with their risk management programme.

As the number and extent of activities involving captives increases, there will be an increasing focus on the relationship between captive insurer and insured. Unlike the position in other jurisdictions, it is unlikely that a dispute in relation to the tax deductibility of premiums paid to a captive insurer is likely to require resort to the New Zealand courts. As noted above however, there are a number of other possible circumstances in which it may be necessary to determine whether the relationship between captive insurer and its insured is one of true insurance.

It is difficult to predict the likely approach of the New Zealand courts to this issue and even more difficult to predict the outcome. Ultimately the recognition or non-recognition of an "insurance" relationship between captive insurer and insured will depend on the circumstances of each particular case and on the mischief giving rise to the litigation. 
(1996) 26 VUWLR 